\title{
PENGARUH HARGA, PRODUKSI DAN TENAGA KERJA TERHADAP PENDAPATAN USAHA PENGOLAHAN GULA AREN DI KECAMATAN RANTAU KABUPATEN ACEH TAMIANG
}

\author{
Thursina Mahyuddin ${ }^{1} /$ Elsa Riski Ananda ${ }^{2}$ \\ ${ }^{1}$ Dosen Tetap Program Studi Agribisnis Fakultas Pertanian \\ ${ }^{2}$ Mahasiswa Fakultas Pertanian Program Studi Agribisnis \\ Universitas Samudra, Langsa-Aceh
}

\section{RINGKASAN}

Tujuan penelitian yaitu untuk mengetahui pengaruh harga, produksi dan tenaga kerja terhadap pendapatan usaha pengolahan gula aren di Kecamatan Rantau Kabupaten Aceh Tamiang. Penelitian ini dilakukan di Kecamatan Rantau Kabupaten Aceh Tamiang dengan menggunakan metode survey. Penentuan lokasi penelitian dilakukan dengan sengaja di Kecamatan Rantau Kabupaten Aceh Tamiang dengan pertimbangan bahwa kecamatan tersebut merupakan daerah sentra usaha pengolahan gula aren. Objek penelitian ini adalah usaha pengolahan gula aren aren yang mengolah air nira aren menjadi gula aren. Ruang lingkup penelitian meliputi harga, produksi, penggunaan tenaga kerja dan pendapatan pada usaha pengolahan gula aren. Model analisis data yang digunakan dalam penelitian ini adalah dengan menggunakan regresi linear berganda.

Hasil penelitian: Karakteristik pengusaha sampel adalah umur rata-rata pengusaha gula aren sampel adalah 46,29 tahun, tingkat pendidikan rata-rata adalah 9,10 tahun, pengalaman berusaha gula aren 10,10 tahun dan jumlah tanggungan keluarga pengusaha gula aren rata-rata 4 orang. Rata-rata luas lahan usaha pengolahan gula aren sampel adalah sebesar $28,71 \mathrm{~m}^{2}$, rata-rata pengunaan tenaga kerja usaha pengolahan gula aren di Kecamatan Rantau yaitu sebesar 56,41 HKP/Tahun, rata-rata biaya produksi usaha pengolahan gula aren di Kecamatan Rantau yaitu sebesar Rp. 8.507.053,76/tahun, rata-rata produksi usaha pengolahan gula aren di Kecamatan Rantau yaitu sebesar $1.849,06 \mathrm{Kg} /$ tahun, rata-rata pendapatan kotor usaha pengolahan gula aren di Kecamatan Rantau yaitu sebesar Rp.35.067.419,35/tahun dan rata-rata pendapatan bersih usaha pengolahan gula aren di Kecamatan Rantau yaitu sebesar Rp.26.560.365,59/tahun.

Hasil perhitungan analisis linier berganda diperoleh persamaan regresi sebagai berikut: $\mathrm{Y}=$ $97,841+1,741 X_{1}+15,797 X_{2}-0,00041 X_{3}$. Nilai $R^{2}$ sebesar 0,9798 artinya bahwa variabel harga $\left(\mathrm{X}_{1}\right)$, produksi $\left(\mathrm{X}_{2}\right)$ dan tenaga kerja $\left(\mathrm{X}_{3}\right)$ mempengaruhi pendapatan $(\mathrm{Y})$ usaha pengolahan gula aren di Kecamatan Rantau sebesar 97,98 \%. Sisanya sebesar 2,02 \% dipengaruhi faktor lain yang tidak dimasukan dalam model penelitian ini. Secara serempak variabel harga $\left(\mathrm{X}_{1}\right)$, produksi $\left(\mathrm{X}_{2}\right)$ dan tenaga kerja $\left(\mathrm{X}_{3}\right)$ berpengaruh sangat nyata terhadap pendapatan $(\mathrm{Y})$ usaha pengolahan gula aren di Kecamatan Rantau. Secara terpisah variabel harga $\left(X_{1}\right)$ dan tenaga Kerja $\left(X_{3}\right)$ tidak berpengaruh nyata sedangkan produksi $\left(\mathrm{X}_{2}\right)$ berpengaruh sangat nyata terhadap pendapatan $(\mathrm{Y})$ usaha pengolahan gula aren di Kecamatan Rantau.

Kata kunci: usaha, gula aren, harga , produksi, tenaga kerja, pendapatan

\section{PENDAHULUAN \\ Latar Belakang}

Aren memiliki potensi ekonomi yang tinggi karena hampir semua bagiannya dapat memberikan keuntungan finansial. Buahnya dapat dibuat kolang-kaling yang digemari oleh masyarakat Indonesia pada umumnya. Daunnya dapat digunakan sebagai bahan kerajinan tangandan bisa juga sebagai atap, sedangkan akarnya dapat dijadikan bahan obat-obatan. Dari batangnya dapat diperoleh ijuk dan lidi yang memiliki nilai ekonomis. Selain itu, batang usia muda dapat diambil sagunya, sedangkan pada usia tua dapat dipakai sebagai bahan perabot. Namun AGRISAMUDRA, Jurnal Penelitian Vol. 4 No.2 Julii - Desember 2017 darisemua produkaren,nira yang berasal dari lengan bunga jantan sebagai bahan untuk produksigula aren dan atau gula semut adalah yang paling besar nilai ekonomisnya.

Diantara jenis-jenis industri tanaman pertanian yang ada di Indonesia salah satunya adalah aren (Arenga pinnata, Merr) yaitu palma yang terpenting setelah kelapa (nyiur) karena merupakan tanaman serba guna. Tumbuhan ini dikenal dengan berbagai nama seperti nau, hanau, peluluk, biluluk, kabung, juk atau ijuk (aneka nama lokal di Sumatra dan Semenanjung Malaya); kawung, taren, akol, akel, akere, inru, indu (bahasa-bahasa di Sulawesi); moka, moke, tuwa, tuwak (di Nusa 
Tenggara), dan lain-lain. Bangsa Belanda mengenalnya sebagai arenpalm atau zuikerpalm dan bangsa Jerman menyebutnya zuckerpalme. Dalam bahasa Inggris disebut sugar palm atau Gomutipalm (Slamet Soeseno, 2000:48).

Gula aren merupakan produk agroindustri yang diproduksi oleh industri rumah tangga yang umumnya berada di pedesaan. Proses pembuatan gula aren tersebut biasanya dilakukan secara tradisional dan menggunakan peralatan sederhana, jumlah produk yang dihasilkan terbatas. Untuk peningkatan nilai tambah pembuatan gula aren oleh industri rumah tangga.

Gula aren diperoleh dengan menyadap tandan bunga jantan yang mulai mekar dan menghamburkan serbuk sari yang berwarna kuning. Tandan ini mula-mula dimemarkan dengan memukul-mukulnya selama beberapa hari, hingga keluar cairan dari dalamnya. Tandan kemudian dipotong dan diujungnya digantungkan tahang bambu untuk menampung cairan yang menetes. Cairan manis yang diperoleh dinamai nira, berwarna jernih agak keruh. Nira ini tidak tahan lama, maka wadah bambu yang telah berisi harus segera diambil untuk diolah niranya, biasanya sehari dua kali pengambilan yakni pagi dan sore.

Di Kecamatan Rantau Kabupaten Aceh Tamiang para petani aren memproduksi gula aren dalam bentuk cair dan padat. Permintaan gula aren sebagai bahan makanan pengganti gula pasir dan pemanis buatan ini menyebabkan aren menjadi komoditi andalan bagi para petani aren. Peningkatan permintaan gula aren di masyarakat merupakan peluang utama bagi para petani untuk berupaya meningkatkan pendapatannya. Peningkatan pendapatan dilakukan dengan melakukan penambahan produksi sehingga nilai produksinya juga meningkat.

Setiap petani dalam pengelolaan usahataninya mempunyai tujuan yang berbeda-beda. Tujuan usahatani pertama adalah untuk memenuhi kebutuhan keluarga dan yang kedua bertujuan mencari keuntungan secara komersial. Petani kita umumnya bertujuan untuk mencari keuntungan dalam meningkatkan penghasilan/ pendapatannya bukan semata-mata untuk memenuhi kebutuhan keluarga.
Harga merupakan satuan ukuran suatu barang atau jasa. Harga merupakan komponen yang berpengaruh langsung terhadap laba usaha. Salah satu gejala ekonomi yang penting bagi petani baik sebagai produsen maupun sebagai konsumen adalah harga. Suatu barang mempunyai harga karena dua sebab, yaitu barang itu berguna dan jumlahnya terbatas.

Produksi adalah berkaitan dengan cara bagaimana sumber daya (masukan) dipergunakan untuk menghasilkan produk (keluaran). Produksi merupakan hasil akhir dari proses atau aktivitas ekonomi dengan memanfaatkan beberapa masukan atau input. Produksi atau memproduksi menambah kegunaan (nilai guna) suatu barang.

Tenaga kerja merupakan faktor penting dalam usaha tani keluarga, khususnya tenaga kerja petani bersama anggota keluarganya. Rumah tangga tani yag umumnya sangat terbatas kemampuannya dari segi modal, peranan tenaga kerja keluarga sangat menentukan. Jika masih dapat diselesaikan oleh tenaga kerja keluarga sediri maka tidak perlu mengupah tenaga luar, yang berarti menghemat biaya. Baik dalam usahatani keluarga maupun perusahaan pertanian peranan tenaga kerja belum belum sepenuhnya diatasi dengan tekologi yang menghemat tenaga (teknologi mekanis). Hal ini dikarenakan selain mahal juga ada hal-hal tertentu yang memang tenaga kerja manusia tidak dapat digantikan.

Besarnya pendapatan yang akan diperoleh dari suatu kegiatan usahatani tergantung dari beberapa faktor yang mempengaruhinya seperti luas lahan, tingkat produksi, identitas pengusaha, pertanaman, dan efisiensi penggunaan tenaga kerja. Dalam melakukan kegiatan usahatani, petani berharap dapat meningkatkan pendapatannya sehingga kebutuhan hidup sehari-hari dapat terpenuhi.

Usaha gula aren merupakan usaha yang dilakukan oleh petani dengan mengelola input produksi yang tersedia untuk memperoleh hasil (produksi). Biaya-biaya produksi atau biaya-biaya yang dikeluarkan untuk biaya usaha gula aren terdiri dari biaya pemeliharaan kebun aren, tenaga kerja, bahan baku, dan modal untuk pengolahan aren. Jumlah produksi yang akan dihasilkan mempengaruhi penerimaan petani, dimana 
besarnya produksi tersebut ditentukan oleh produktivitas usaha gula aren tersebut. Penerimaan juga dipengaruhi oleh harga jual gula aren dan penerimaan adalah jumlah produksi dikalikan dengan harga jual gula aren ke pasaran. Usaha pengolahan gula aren yang ada di Kecamatan Rantau umumnya sudah mengarah pada tujuan untuk mencari keuntungan secara komersial. Akan tetapi pengusaha gula aren tidak pernah menghitung berapa besar pendapatan usaha yang dijalankan, serta tidak mengetahui bagaimana pengaruh dari faktor yang mempengaruhi pendapatan tersebut. Sehubungan dengan hal tersebut diatas, maka penulis merasa tertarik dan penting untuk meneliti lebih lanjut tentang pengaruh harga, produksi dan tenaga kerja terhadap pendapatan usaha pengolahan gula aren di Kecamatan Rantau Kabupaten Aceh Tamiang.

\section{Identifikasi Masalah}

"Apakah harga, produksi dan tenaga kerja berpengaruh terhadap pendapatan usaha pengolahan gula aren di Kecamatan Rantau Kabupaten Aceh Tamiang?"

\section{Tujuan Penelitian}

"Untuk mengetahui pengaruh harga, produksi dan tenaga kerja terhadap pendapatan usaha pengolahan gula aren di Kecamatan Rantau Kabupaten Aceh Tamiang"

\section{Hipotesis Penelitian}

"Harga, produksi dan tenaga kerja berpengaruh terhadap pendapatan usaha pengolahan gula aren di Kecamatan Rantau Kabupaten Aceh Tamiang"

\section{METODOLOGI PENELITIAN}

\section{Lokasi, Objek, Ruang Lingkup dan Waktu Penelitian}

Penelitian ini dilakukan di Kecamatan

Rantau Kabupaten Aceh Tamiang dengan menggunakan metode survey. Menurut Sugiono (2012:6), "Metode survey digunakan untuk mendapatkan data dari suatu tempat tertentu yang alamiah (bukan buatan), tetapi peneliti melakukan perlakuan dalam pengumpulan data yaitu dengan mengedarkan observasi, wawancara, kuisioner dan sebagainya (perlakuan tidak seperti eksperimen)". Penentuan lokasi penelitian dilakukan dengan sengaja di Kecamatan Rantau Kabupaten Aceh Tamiang dengan pertimbangan bahwa kecamatan tersebut merupakan daerah sentra usaha pengolahan gula aren. Objek penelitian ini adalah usaha pengolahan gula aren aren yang mengolah air nira aren menjadi gula aren. Ruang lingkup penelitian meliputi harga, produksi, penggunaan tenaga kerja dan pendapatan pada usaha pengolahan gula aren.

\section{Teknik Penentuan Sampel dan Pengumpulan Data Penentuan Sampel}

Populasi dalam penelitian ini adalah pengusaha gula aren yang berada di Kecamatan Rantau. Kecamatan Rantau terdiri dari 16 Desa dimana terdapat 7 desa yang terdapat usaha pengolahan gula aren. Dari 7 desa tersebut diambil 3 desa untuk dijadikan sampel secara purposive, dengan pertimbangan bahwa 3 desa tersebut yang memilki jumlah pengusaha aren yang terbanyak. Metode pengambilan pengusaha sampel dalam penelitian ini dilakukan dengan menggunakan metode sampel jenuh (Total Sampling). Artinya semua populasi dijadikan sampel penelitian karena jumlah populasi yang kecil. Sedangkan menurut Sudjana, (2003:96) menyatakan "Sebaliknya bila populasi kecil, sampel dirumuskan mendekati jumlah populas i’. Untuk lebih jelasnya mengenai jumlah populasi dan pengusaha sampel di daerah penelitian dapat dilihat pada tabel III-1 berik ut ini:

Tabel III-1. Jumlah Populasi dan Jumlah Sampel Pengusaha Gula Aren Untuk Masing-masing Desa di Kecamatan Rantau Kabupaten Aceh Tamiang, 2016

\begin{tabular}{|r|l|l|l|}
\hline No & Nama Desa & Populasi & Sampel \\
\hline 1 & Ingin Jaya & 10 & 10 \\
2 & Jamur Labu & 11 & 11 \\
3 & Durian & 10 & 10 \\
\hline \multicolumn{2}{|l|}{ Jumlah } & 31 & 31 \\
\hline
\end{tabular}

Sumber Data : BPS Aceh Tamiang, 2017 
Tabel III-1 menunjukan bahwa jumlah populasi pengusaha gula aren yaitu sebanyak 31 orang yang semuanya dijadikan sampel penelitian terdiri dari Desa Ingin Jaya sebanyak 10 orang, Desa Jamur Labu sebanyak 11 orang dan Desa Durian sebanyak 10 orang..

\section{Metode Analisis dan Pengujian Hipotesis}

Data yang diperoleh dari lapangan baik data primer maupun data sekunder diolah dengan mentabulasikan dan kemudian dipindahkan ke dalam bentuk tabelaris sesuai dengan kebutuhan analisis.

\section{Analisis Pendapatan}

1) Pendapatan Kotor

$\mathrm{TR}=(\mathrm{Y}) \mathrm{x}(\mathrm{Py}) \ldots \ldots . \quad($ Ken

Suratiyah, $2006: 65$ )

Keterangan:

TR : Total penerimaan (Total Revenue) (Rp/Tahun)

$\mathrm{Y}$ : Produksi pengolahan gula aren $(\mathrm{Kg} / \mathrm{Tahun})$

Py : Harga gula aren (Price) $(\mathrm{Rp} / \mathrm{Kg})$

2) Pendapatan Bersih

$$
\mathrm{Pd}=\mathrm{TR}-\mathrm{TC} \ldots . . \quad(
$$

Soekartawi, 2002:58)

Keterangan :

Pd : Pendapatan usaha gula aren $(\mathrm{Rp} / \mathrm{Tahun})$

TR : Penerimaan Total

(total revenue) (Rp/Tahun)

TC : Biaya total (total cost) (Rp/Tahun)

\section{Pengujian Hipotesis}

Data yang dikumpulkan di lapangan kemudian diolah dengan cara mentabulasikan dalam bentuk tabelaris sesuai dengan kebutuhan analisis. Model analisis yang menunjukkan bentuk hubungan antara variabel-variabel bebas dengan variabel terikat dapat dirumuskan sebagai berikut :

$$
\mathrm{Y}=\mathrm{f}\left(\mathrm{X}_{1}, \mathrm{X}_{2}, \mathrm{X}_{3}\right)
$$

Data yang dikumpulkan dilapangan diolah dan ditabulasikan menurut kebutuhan analisis. Model yang digunakan dalam penelitian ini adalah dengan menggunakan regresi linear berganda. Menurut Lubis (2009:89) "Analisis Regresi Linier Berganda adalah hubungan secara linier antara dua atau lebih variabel independen (bebas) dengan variabel dependen (tak bebas). Kejadian diperolehnya hubungan linier antara variabel bebas dengan variabel tak bebas atau adanya variabel bebas yang merupakan fungsi linier dari variabel tak bebas. Model tersebut dapat ditulis sebagai berikut:

$$
\mathrm{Y}=\mathrm{a}_{0}+\mathrm{a}_{1} \mathrm{X}_{1}+\mathrm{a}_{2} \mathrm{X}_{2}+\mathrm{a}_{3} \mathrm{X}_{3}+\mathrm{e}
$$

Dimana :

$$
\mathrm{Y} \quad=\text { Pendapatan usaha }
$$

pengolahan gula aren $(\mathrm{Rp} / \mathrm{Thn})$

$$
\begin{array}{ll}
\mathrm{X}_{1} & =\text { Harga Gula Aren } \\
(\mathrm{Rp} / \mathrm{Kg}) & =\text { Produksi }(\mathrm{Kg} / \mathrm{Thn}) \\
\mathrm{X}_{2} & =\text { Tenaga Kerja } \\
\mathrm{X}_{3} & \\
(\mathrm{HKP} / \mathrm{Thn}) & \\
\mathrm{a}_{1,} \mathrm{a}_{2} \text { dan } \mathrm{a}_{3} & =\text { Koefisien regresi } \\
\text { yang dicari } & =\text { Intercept } \\
\mathrm{a}_{0} & =\text { Standar error } \\
\mathrm{e} & \\
\text { Selanjutnya } & \text { dihitung koefisien }
\end{array}
$$
determinasi $\left(\mathrm{R}^{2}\right)$ untuk mengetahui besarnya pengaruh secara keseluruhan. "Analisis determinasi dalam regresi linear berganda digunakan untuk mengetahui persentase sumbangan pengaruh variabel independen secara serentak terhadap variabel dependen. (Sudjana, 2005:382)

Untuk melihat besarnya koefisien determinasi $\left(\mathrm{R}^{2}\right)$ digunakan rumus sebagai berikut:

$$
R^{2}=\frac{J K_{r e g}}{\sum y_{i}^{2}}
$$

2002:383)

.(Sudjana,

$$
\begin{array}{ll}
\multicolumn{2}{l}{\text { Keterangan: }} \\
\mathrm{R}^{2} & =\text { Koefisien determinasi } \\
\mathrm{JK}_{\mathrm{reg}} & =\text { Jumlah kuadrat regresi } \\
\sum \mathrm{yi}^{2} & =\text { Jumlah kuadrat total }
\end{array}
$$

Uji $F$ digunakan untuk menunjukkan apakah keseluruhan variabel bebas berpengaruh terhadap variabel dependen dengan menggunakan Level of significance 5 dan 1 persen (Sugiyono, 2007:122). Untuk menguji pengaruh secara serempak variabel independen $\left(\mathrm{X}_{1}, \mathrm{X}_{2}\right.$ dan $\left.\mathrm{X}_{3}\right)$ terhadap variabel dependen $(\mathrm{Y})$, digunakan Uji $\mathrm{F}$ yaitu:

$$
F=\frac{J K_{r e g} / k}{J K_{r e s} /(n-k-1)}
$$




$J K_{\text {reg }}=a_{1} \sum x_{1 i} y_{i}+a_{2} \sum x_{2 i} y_{i}+$
$\ldots .+a_{k} \sum x_{k i} y_{i} \ldots \ldots \ldots \ldots($ Sudjana, 2002:354 $)$
$J K_{\text {res }}=\sum\left(Y_{i}-Y_{i}\right){ }^{2}$

na, 2002:355)

Keterangan:

$\mathrm{JK}_{\text {reg }}=$ Jumlah kuadrat-kuadrat untuk regresi

$$
\begin{array}{ll}
\mathrm{k} & =\text { Banyaknya variabel bebas } \\
\mathrm{JK}_{\text {res }} & =\text { Jumlah kuadrat-kuadrat }
\end{array}
$$

residu

$$
\mathrm{n} \quad=\text { Jumlah sampel }
$$

Dengan kaidah keputusan :

$\mathrm{F}$ hitung $<\mathrm{F}$ tabel maka terima Ho tolak Ha tolak Ho

$\mathrm{F}$ hitung $>\mathrm{F}$ tabel maka terima $\mathrm{Ha}$

Ha : Harga, produksi dan tenaga kerja secara serempak berpengaruh terhadap pendapatan usaha pengolahan gula aren di Kecamatan Rantau Kabupaten Aceh Tamiang.

Ho : Harga, produksi dan tenaga kerja secara serempak tidak berpengaruh terhadap pendapatan usaha pengolahan gula aren di Kecamatan Rantau Kabupaten Aceh Tamiang

Uji t ini digunakan untuk mengetahui apakah masing-masing variabel bebas secara sendiri-sendiri mempunyai pengaruh secara signifikan terhadap variabel dependen (Sugyiono, 2007:126). Untuk mengetahui pengaruh variabel bebas (independen) terhadap variabel tak bebas (dependen) secara parsial digunakan uji " $\mathrm{t}$ " dengan rumus :

$$
t=\frac{a_{i}}{S a_{i}}
$$

2002:388)

..(Sudjana,

Keterangan:

$\mathrm{S}_{\mathrm{ai}}=$ Standar error dari koefisien regresi

$\mathrm{t}=$ Uji secara parsial

$\mathrm{a}_{\mathrm{i}} \quad=$ Koefisien regresi yang

Kriteria penerimaan/penolakan hipotesis

Jika $\mathrm{t}$ cari $\leq \mathrm{t}$ tabel maka terima Ho dan tolak Ha

Jika $t$ cari $>\mathrm{t}$ tabel maka tolak Ho dan terima $\mathrm{Ha}$

Keterangan:
Ha : Harga, produksi dan tenaga kerja secara terpisah berpengaruh terhadap pendapatan usaha pengolahan gula aren di Kecamatan Rantau Kabupaten Aceh Tamiang.

Ho : Harga, produksi dan tenaga kerja secara terpisah tidak berpengaruh terhadap pendapatan usaha pengolahan gula aren di Kecamatan Rantau Kabupaten Aceh Tamiang.

\section{Asumsi Dasar Penelitian}

1. Waktu perhitungan usaha selama 1 (satu) tahun operasional produksi usaha pengolahan gula aren

2. Upah tenaga kerja disetarakan $\mathrm{Rp}$ 50.000 per HKP

\section{HASIL PENELITIAN DAN PEMBAHASAN}

Karakteristik Pengusaha gula aren Sampel Karakteristik pengusaha gula aren dalam penelitian ini meliputi umur, pendidikan, pengalaman dalam berusaha pengolahan gula aren dan besar tanggungan keluarga. Rini (2005:26), "pengertian karakteristik individu adalah bagian dari pribadi dan melekat pada diri seseorang. Karakteristik ini mendasari tingkah laku seseorang dalam situasi kerja maupun situasi yang lainnya”. Karakteristik akan mempengaruhi pengusaha gula aren dalam mengelola usahatani selama proses produksi berlangsung. Pengusaha gula aren dalam menjalankan usahanya memiliki fungsi ganda yaitu disamping sebagai manager usahatani juga sebagai buruh. Umur rata-rata pengusaha gula aren sampel adalah 46,29 tahun, umur tersebut adalah umur yang produktif dalam mengusahakan usaha pengolahan gula aren. Tingkat pendidikan rata-rata adalah 9,10 tahun, pendidikan pengusaha gula aren sampel masih rendah. Semakin tinggi tingkat pendidikan pengusaha gula aren, maka semakin kreatif pengusaha gula aren dalam mengambil berbagai tindakan usaha, begitu juga sebaliknya semakin rendah tingkat pendidikan Pengusaha gula aren maka semakin lambat dalam mengambil berbagai keputusan usaha. Rata-rata pengalaman berusaha gula aren 10,10 tahun, pengalaman dalam berusaha pengolahan gula aren cukup lama sehingga kegagalan dan resiko yang akan dihadapi akan semakin kecil dan dapat 
dikatakan cukup mahir dalam menjalankan usaha pengolahan gula aren. Jumlah tanggungan keluarga pengusaha gula aren ratarata 4 orang, menunjukkan bahwa Jumlah tanggungan keluarga rata-rata 4 orang merupakan tanggungan yang kecil sehingga pengusaha gula aren bisa membiayai usaha dengan baik.Rata-rata luas lahan usaha pengolahan gula aren sampel adalah sebesar $28,71 \mathrm{~m}^{2}$, dimana luas lahan usaha yang terbesar terdapat pada Desa Ingin Jaya sebesar $29,90 \mathrm{~m}^{2}$ dan luas lahan yang terkecil terdapat pada Desa Jamur Labu yaitu sebesar 27,30 $\mathrm{m}^{2}$.

\section{Penggunaan Tenaga Kerja}

Penggunaan tenaga kerja pada usaha pengolahan gula aren meliputi kegiatan penyadapan aren, pengangkutan, pemasakan gula, pencetakan, pengemasan dan pemasaran. Dalam menghitung besarnya pencurahan tenaga kerja yang diserap untuk setiap fase kegiatan, seluruhnya dikonversikan ke dalam Hari Kerja Pria (HKP). Rata-rata penggunaan tenaga kerja usaha pengolahan gula aren di Kecamatan Rantau dilihat pada tabel V-3 berikut.

Tabel V-3. Rata-Rata Penggunaan Tenaga Kerja Usaha pengolahan gula aren di Kecamatan Rantau, 2017

\begin{tabular}{|l|l|c|c|c|}
\hline No & Nama Desa & & & \\
& & TKDK (HKP/Tahun) & TKLK (HKP/Tahun) & Total TK (HKP/Tahun) \\
\hline 1 & Ingin Jaya & 47,72 & 5,99 & 53,71 \\
2 & Jamur Labu & 48,34 & 6,24 & 54,58 \\
3 & Durian & 54,02 & 6,52 & 60,54 \\
\hline \multicolumn{2}{r|}{ Rata-rata } & 50,15 & 6,26 & 56,41 \\
\hline
\end{tabular}

Sumber : Data Primer diolah, 2017

Tabel V-3 di atas dapat dilihat bahwa rata-rata pengunaan tenaga kerja usaha pengolahan gula aren di Kecamatan Rantau yaitu sebesar 56,41 HKP/Tahun. Rata-rata penggunaan tenaga kerja terbesar di Desa Durian sebesar 60,54 HKP/Tahun dan terkecil

\section{Biaya Produksi Usaha Pengolahan Gula} Aren

Rata-rata penggunaan biaya produksi perusaha sampel pada usaha pengolahan gula aren di Kecamatan Rantau dapat dilihat pada tabel V-4 berikut. di Desa Ingin Jaya sebesar 53,71 HKP/Tahun.

Tabel V-4. Rata-Rata Biaya Produksi Usaha Pengolahan Gula Aren di Kecamatan Rantau, 2017

\begin{tabular}{|c|l|r|r|c|}
\hline No & Nama Desa & $\begin{array}{l}\text { Biaya Tetap } \\
\text { (Rp/Tahun) }\end{array}$ & $\begin{array}{l}\text { Biaya Variabel } \\
\text { (Rp/Tahun) }\end{array}$ & Total Biaya (Rp/Tahun) \\
\hline 1 & Ingin Jaya & $802.595,00$ & $7.771 .240,00$ & $8.573 .835,00$ \\
2 & Jamur Labu & $766.515,00$ & $7.121 .470,00$ & $7.887 .985,00$ \\
3 & Durian & $798.687,88$ & $8.210 .445,45$ & $9.009 .133,33$ \\
\hline & Rata-rata & $789.569,89$ & $7.717 .483,87$ & $8.507 .053,76$ \\
\hline
\end{tabular}

Sumber : Data Primer diolah, 2017

Tabel V-4 di atas dapat dilihat ratarata total biaya produksi usaha pengolahan gula aren di Kecamatan Rantau yaitu sebesar Rp. 8.507.053,76/tahun. Rata-rata penggunaan biaya tetap sebesar Rp. 789.569,89/tahun dan biaya variabel sebesar Rp. 7.717.483,87/tahun. Total biaya produksi terbesar terdapat pada
Desa Durian sebesar Rp. 9.009.133,33/tahun dan total biaya produksi terkecil terdapat pada Desa Jamur Labu sebesar Rp. 7.887.985/tahun.

\section{Produksi Usaha Pengolahan Gula Aren}

Rata-rata produksi usaha pengolahan gula aren di Kecamatan Rantau dapat dilihat pada tabel V-5 berikut ini. 
Tabel V-5. Rata-Rata Produksi Pada Usaha Pengolahan Gula Aren di Kecamatan Rantau, 2017

\begin{tabular}{|l|l|l|}
\hline No & Nama Desa & Produksi (Kg/Tahun) \\
\hline 1 & Ingin Jaya & $1.947,50$ \\
2 & Jamur Labu & $1.770,70$ \\
3 & Durian & $1.830,82$ \\
\hline
\end{tabular}

Sumber : Data Primer diolah, 2017

Tabel V-5 dapat dilihat bahwa rata-rata produksi usaha pengolahan gula aren di Kecamatan Rantau yaitu sebesar 1.849,06 $\mathrm{Kg} /$ tahun. Rata-rata produksi tertinggi berada di Desa Ingin Jaya yaitu sebesar 1.947,5 $\mathrm{Kg} / \mathrm{tahun}$ dan terkecil berada di Desa Jamur Labu sebesar 1.770,7 Kg/tahun.

\section{Nilai Produksi (Pendapatan Kotor) Usaha Pengolahan Gula Aren}

Nilai produksi (pendapatan kotor) adalah total perkalian produksi dan harga

Tabel V-6. Rata-Rata Nilai Produksi Pada Usaha Pengolahan Gula Aren Kecamatan Rantau, 2017

\begin{tabular}{|l|l|l|}
\hline No & Nama Desa & Nilai Produksi (Rp/Tahun) \\
\hline 1 & Ingin Jaya & $37.026 .250,00$ \\
2 & Jamur Labu & $33.716 .500,00$ \\
3 & Durian & $34.514 .772,73$ \\
\hline \multicolumn{2}{|l|}{ Rata-rata } & $35.067 .419,35$ \\
\hline
\end{tabular}

Tabel V-6 di atas dapat dilihat bahwa rata-rata pendapatan kotor usaha pengolahan gula aren di Kecamatan Rantau yaitu sebesar Rp.35.067.419,35/tahun. Rata-rata nilai produksi tertinggi berada di Desa Ingin Jaya yaitu sebesar Rp.37.026.250/tahun dan terkecil berada di Desa Jamur Labu sebesar Rp.33.716.500/tahun. 2017

\begin{tabular}{|l|l|r|r|r|}
\hline No & Nama Desa & \multicolumn{1}{|l|}{$\begin{array}{l}\text { Nilai Produksi } \\
\text { (Rp/Tahun) }\end{array}$} & $\begin{array}{l}\text { Biaya Produksi } \\
\text { (Rp/Tahun) }\end{array}$ & $\begin{array}{l}\text { Pendapatan } \\
\text { (Rp/Tahun) }\end{array}$ \\
\hline 1 & Ingin Jaya & $37.026 .250,00$ & $8.573 .835,00$ & $28.452 .415,00$ \\
2 & Jamur Labu & $33.716 .500,00$ & $7.887 .985,00$ & $25.828 .515,00$ \\
3 & Durian & $34.514 .772,73$ & $9.009 .133,33$ & $25.505 .639,39$ \\
\hline \multicolumn{2}{|r|r|}{ Rata-rata } & $35.067 .419,35$ & $8.507 .053,76$ & $26.560 .365,59$ \\
\hline
\end{tabular}

Sumber : Data Primer diolah, 2017

Tabel V-7 di atas dapat dilihat bahwa rata-rata pendapatan bersih usaha pengolahan produksi yang diterima pengusaha gula aren dari usahanya. Besarnya nilai produksi sangat ditentukan oleh harga yang berlaku saat pengusaha gula aren menjual hasil produksinya. Pada saat penelitian ini dilakukan harga gula aren di Kecamatan Rantau adalah Rp. 17.500 - Rp. 20.000 per kilogram. Rata-rata nilai produksi usaha pengolahan gula aren di Kecamatan Rantau dapat dilihat pada tabel V-6 berikut ini.

\section{Pendapatan Bersih Usaha Pengolahan Gula} Aren

Pendapatan bersih sangat dipengaruhi oleh besarnya nilai produksi dan besarnya biaya produksi usaha pengolahan gula aren. Pendapatan bersih yaitu selisih antara nilai produksi dengan total biaya produksi. Ratarata pendapatan bersih usaha pengolahan gula aren di Kecamatan Rantau dapat dilihat pada tabel V-7 berikut ini.
Tabel V-7. Rata-Rata Pendapatan Bersih Usaha Pengolahan Gula Aren di Kecamatan Rantau, gula aren di Kecamatan Rantau yaitu sebesar Rp.26.560.365,59/tahun. Rata-rata pendapatan

AGRISAMUDRA, Jurnal Penelitian Vol. 4 No.2 Julii - Desember 2017 
bersih tertinggi berada di Desa Ingin Jaya yaitu sebesar Rp.28.452.415/tahun dan terkecil berada di Desa Durian sebesar Rp.25.505.639,39/tahun.

Analisis Pengaruh Harga, Produksi dan Tenaga Kerja Terhadap Pendapatan Usaha pengolahan gula aren di Kecamatan Rantau

Untuk menganalisis pengaruh harga, produksi dan tenaga kerja terhadap pendapatan usaha pengolahan gula aren di Kecamatan Rantau digunakan model analisis regresi linier berganda. Hasil perhitungan analisis linier berganda diperoleh persamaan regresi sebagai berikut:

$$
Y=-97,841+1,741 X_{1}+15,797 X_{2}-
$$
$0,00041 \mathrm{X}_{3}$

Dengan interprestasi sebagai berikut:

- Nilai konstanta sebesar -97,841 artinya jika harga $\left(\mathrm{X}_{1}\right)$, produksi $\left(\mathrm{X}_{2}\right)$ dan tenaga kerja $\left(\mathrm{X}_{3}\right)$ dianggap tidak ada maka pendapatan usaha pengolahan aren di Kecamatan Rantau berkurang sebesar Rp. 97.841.000/tahun.

- Koefisien regresi variabel harga $\left(X_{1}\right)$ sebesar 1,741. Artinya bila produksi dan tenaga kerja dianggap tetap maka setiap penambahan harga sebesar Rp.1.000/Kg gula aren akan menyebabkan pendapatan meningkat sebesar Rp.1.741.000/Tahun.

- Koefisien regresi variabel produksi $\left(\mathrm{X}_{2}\right)$ sebesar 15,797. Artinya bila harga dan tenaga kerja dianggap tetap maka setiap penambahan produksi gula aren 1.000 $\mathrm{Kg}$ /Tahun akan menyebabkan pendapatan meningkat sebesar Rp.15.797.000/Tahun.

- Koefisien regresi variabel tenaga kerja $\left(X_{3}\right)$ sebesar - 0.00041. Artinya bila harga dan produksi dianggap tetap maka setiap penambahan tenaga kerja sebanyak 1 HKP akan menyebabkan pendapatan menurun sebesar Rp.410/Tahun.

\section{Uji $\mathbf{R}^{2}$ (Koefisien Determinasi)}

Hasil analisis data secara regresi linier berganda menghasilkan nilai $\mathrm{R}^{2}$ sebesar 0,9798 artinya bahwa variabel harga $\left(\mathrm{X}_{1}\right)$, produksi $\left(\mathrm{X}_{2}\right)$ dan tenaga kerja $\left(\mathrm{X}_{3}\right)$ mempengaruhi pendapatan (Y) usaha pengolahan gula aren di Kecamatan Rantau sebesar $97,98 \%$. Sisanya sebesar 2,02\% dipengaruhi faktor lain yang tidak dimasukan dalam model penelitian ini.

\section{Uji F (Pengaruh Serempak)}

Hasil pengujian pengaruh serempak disajikan pada Tabel V.8 berikut:

Tabel V.8. Hasil Regresi Uji F

\begin{tabular}{|c|l|l|c|}
\hline \multirow{2}{*}{$\mathrm{F}_{\text {cari }}$} & \multicolumn{2}{|c|}{$\mathrm{F}_{\text {tabel }}$} & Kesimpulan \\
\cline { 2 - 4 } & $\alpha=0,05$ & $\alpha=0,01$ & \\
\hline 437,367 & 3,335 & 5,480 & $\mathrm{~F}_{\text {cari }}>\mathrm{F}_{\text {tabel }}$ \\
& & & $\alpha=0,05$ dan $\alpha=0,01$ \\
\hline
\end{tabular}

Sumber : Data Primer diolah, 2017

Tabel di atas menunjukkan hasil analisis data secara regresi linier berganda diperoleh nilai $F_{\text {cari }}$ sebesar 437,367 . Nilai $F_{\text {tabel }}$ adalah $5,480(\alpha=0,01)$ dan 3,335 $(\alpha=0,05)$. Berarti $\mathrm{F}_{\text {cari }}>$ dari $\mathrm{F}_{\text {tabel }}$ pada tingkat keyakinan $95 \%$ dan $99 \%$. Artinya secara serempak variabel harga $\left(\mathrm{X}_{1}\right)$, produksi $\left(\mathrm{X}_{2}\right)$ dan tenaga kerja Tabel V.9. Hasil Regresi Uji t

\begin{tabular}{|l|l|l|l|l|}
\hline \multirow{2}{*}{ Variabel } & \multirow{2}{*}{$\mathrm{t}_{\text {cari }}$} & \multicolumn{2}{|c|}{$\mathrm{t}_{\text {tabel }}$} & \multirow{2}{*}{ Kesimpulan } \\
\cline { 3 - 5 } & & 0,05 & 0,01 & \\
\hline Harga $\left(\mathrm{X}_{1}\right)$ & 0,860 & 1,6991 & 2,462 & \\
\hline Produksi $\left(\mathrm{X}_{2}\right)$ & 8,0997 & 1,6991 & 2,462 & $\begin{array}{l}\mathrm{t}_{\text {cari }}<\mathrm{t}_{\text {tabel }}>\mathrm{t}_{\text {tabel }} \text { pada } \alpha=0,05 \\
\text { dan } \alpha=0,01\end{array}$ \\
\hline Tenaga Kerja $\left(\mathrm{X}_{3}\right)$ & $-0,0002$ & 1,6991 & 2,462 & $\begin{array}{l}\mathrm{t}_{\text {cari }}<\mathrm{t}_{\text {tabel }} \text { pada } \alpha=0,05 \\
\text { dan } \alpha=0,01\end{array}$ \\
\hline
\end{tabular}

Sumber : Data Primer diolah, 2017

Tabel di atas menunjukkan hasil analisis regresi linier berganda diperoleh nilai AGRISAMUDRA, Jurnal Penelitian Vol. 4 No.2 Julii - Desember 2017
$\left(\mathrm{X}_{3}\right)$ berpengaruh sangat nyata terhadap pendapatan (Y) usaha pengolahan gula aren di Kecamatan Rantau.

\section{Uji t (Pengaruh Terpisah)}

Hasil pengujian pengaruh terpisah disajikan pada Tabel V.9 berikut: 
$2,462(\alpha=0,01)$ dan 1,6991 $(\alpha=0,05)$. Untuk variabel harga $\left(X_{1}\right)$ berarti $t_{\text {cari }}<$ dari $t_{\text {tabel }} 2,462$ $(\alpha=0,01)$ dan $1,6991(\alpha=0,05)$, artinya secara terpisah variabel harga $\left(\mathrm{X}_{1}\right)$ tidak berpengaruh nyata terhadap pendapatan (Y) usaha pengolahan gula aren di Kecamatan Rantau. Untuk variabel produksi $\left(\mathrm{X}_{2}\right)$ diperoleh $\mathrm{t}_{\text {cari }}=$ sebesar 8,0997 berarti $t_{\text {cari }}>$ dari $t_{\text {tabel }} 2,462$ $(\alpha=0,01)$ dan $1,6991(\alpha=0,05)$, artinya secara terpisah variabel produksi $\left(\mathrm{X}_{2}\right)$ berpengaruh sangat nyata terhadap pendapatan (Y) usaha pengolahan gula aren di Kecamatan Rantau.

Untuk variabel tenaga kerja $\left(\mathrm{X}_{3}\right)$ berarti $\mathrm{t}_{\text {cari }}<$ dari $\mathrm{t}_{\text {tabel }} 2,462(\alpha=0,01)$ dan $1,6991 \quad(\alpha=0,05)$, artinya secara terpisah variabel tenaga kerja $\left(\mathrm{X}_{3}\right)$ tidak berpengaruh nyata terhadap pendapatan (Y) usaha pengolahan gula aren di Kecamatan Rantau.

\section{Pembahasan}

Variabel harga tidak berpengaruh terhadap pendapatan usaha pengolahan gula aren di Kecamatan Rantau. Penyebab harga tidak berpengaruh terhadap pendapatan usaha pengolahan gula aren karena harga yang diterima oleh pengusaha gula aren tidak berbeda jauh antara satu pengusaha dengan pengusaha yang lain. Sehingga perbedaan harga gula aren yang tercipta tidak terlalu besar, pada akhirnya tidak berpengaruh secara nyata terhadap pendapatan usaha pengolahan gula aren di Kecamatan Rantau Kabupaten Aceh Tamiang.

Variabel produksi berpengaruh sangat nyata terhadap pendapatan usaha pengolahan gula aren di Kecamatan Rantau. Produksi adalah komponen yang utama dalam perhitungan penerimaan usaha pengolahan gula aren. Semakin tinggi produksi akan diikuti semakin besar penerimaan jika biaya produksi bertambah dalam besaran yang sama pendapatan bersih akan semakin bertambah juga. Sehingga produksi akan berpengaruh sangat nyata terhadap penadapatan usaha pengolahan gula aren di Kecamatan Rantau kabupaten Aceh Tamiang.

Variabel tenaga kerja tidak berpengaruh terhadap pendapatan usaha pengolahan gula aren di Kecamatan Rantau. Tenaga kerja memang faktor yang penting dalam usaha pengolahan gula aren. Tenaga kerja umumnya digunakan adalah tenaga kerja dalam keluarga dan jumlahnya juga tidak berbeda jauh antara satu usaha dengan usaha lainnya, sehingga tenaga kerja tidak memberikan pengaruh yang nyata terhadap pendapatan usaha pengalahan gula aren di Kecamatan Rantau Kabupaten Aceh Tamiang.

\section{KESIMPULAN DAN SARAN \\ Kesimpulan}

1. Hasil perhitungan analisis linier berganda diperoleh persamaan regresi sebagai berikut: $Y=-97,841+1,741 X_{1}+15,797$ $\mathrm{X}_{2}-0,00041 \mathrm{X}_{3}$

2. Nilai $R^{2}$ sebesar 0,9798 artinya bahwa variabel harga $\left(\mathrm{X}_{1}\right)$, produksi $\left(\mathrm{X}_{2}\right)$ dan tenaga kerja $\left(\mathrm{X}_{3}\right)$ mempengaruhi pendapatan (Y) usaha pengolahan gula aren di Kecamatan Rantau sebesar 97,98 $\%$. Sisanya sebesar 2,02 \% dipengaruhi faktor lain yang tidak dimasukan dalam model penelitian ini.

3. Secara serempak variabel harga $\left(X_{1}\right)$, produksi $\left(\mathrm{X}_{2}\right)$ dan tenaga kerja $\left(\mathrm{X}_{3}\right)$ berpengaruh sangat nyata terhadap pendapatan (Y) usaha pengolahan gula aren di Kecamatan Rantau.

4. Secara terpisah variabel harga $\left(X_{1}\right)$ dan tenaga Kerja $\left(X_{3}\right)$ tidak berpengaruh nyata sedangkan produksi $\left(\mathrm{X}_{2}\right)$ berpengaruh sangat nyata terhadap pendapatan (Y) usaha pengolahan gula aren di Kecamatan Rantau.

\section{Saran-saran}

1. Diharapkan kepada pengusaha gula aren di Kecamatan Rantau untuk dapat meningkatkan pendapatan usaha yang dikelolanya dengan cara menambah faktor produksi yang mempunyai pengaruh langsung terhadap produktivitas usaha pengolahan gula aren, sehingga pada akhirnya juga akan meningkatkan pendapatan dan kesejahteraan pengusaha

2. Pengusaha gula aren agar dapat meningkatkan kualitas gula aren dengan variasi cetakan, ukuran dan kemasan yang lebih menarik agar harga jual gula aren produksinya dapat lebih tinggi sehingga dapat meningkatkan pendapatan.

3. Pengusaha gula aren hendaknya dapat membuat variasi produk dengan memproduksi gula semut yang memiliki pangsa pasar ke pasar-pasar modern.

4. Perlu adanya penyuluhan secara kontinyu kepada para pengusaha gula aren tentang pentingnya menjalankan usaha pengolahan 
gula aren secara intensif sehingga diharapkan akan meningkatkan produksi yang optimal dan meningkatkan pendapatan pengusaha.

\section{DAFTAR PUSTAKA}

Alwi, 2004. Pasar Modal: Teori dan Aplikasi Cetakan Pertama, Yayasan Pancur Siwah, Jakarta.

Adisasmita, Rahardjo, 2006, Pembangunan Pedesaan dan Perkotaan, Graha Ilmu Yogyakarta.

FAO [Food and Agriculture Organization]. 2014. Guar Gum. http://www.fao.org [7 Juli 2014].

Gittinger, J. Price dan Adler. A Hans. 1993. Analisis Ekonomi ProyekProyek Pertanian. Cetakan Ketiga. PT. Rineka Cipta. Jakarta.

Hadisapoetra. 2000. Biaya dan Pendapatan di Dalam Usahatani. UGM: Yogyakarta

Hernanto, F., 2004. Ilmu Usahatani. Penebar Swadaya, Jakarta.

Husein Umar, 2003. Metode Riset Bisnis, Jakarta: PT Gramedia Pustaka Utama

Husein Umar, 2007. Metode Studi Kelayakan Bisnis, Jakarta: PT Gramedia Pustaka Utama

Ibrahim, Yakob. 2010. Studi Kelayakan Bisnis. Bineka Cipta. Jakarta.

Kadariah, 2001. Evaluasi Proyek : Analisis Ekonomis. Lembaga Penerbitan Fakultas Ekonomi Universitas Indonesia. Jakarta

Ken Suratiyah, 2006. Ilmu Usahatani, Penebar Swadaya, Jakarta

Krisnamurthi, B. 2009. Langkah Sukses Menuju Agribisnis. Penebar Swadaya. Jakarta.

Mubyarto, 2002. Pengantar Ekonomi Pertanian. LP3ES. Jakarta.
Mulyana. 1996. Ekonomi Kedelai di Indonesia (Penyunting :Amang, B., M. H. Sawit dan A. Rachman). IPB Press, Bogor.

Mutiara, A. 2010. Analisis Pengaruh Bahan Baku, Bahan Bakar dan Tenaga Kerja terhadap Produksi Tempe di Kota Semarang. Skripsi. Ilmu Ekonomi dan Studi Pembangunan. Universitas Diponegoro.

Ngangi, 2001. Agroindustri Membangun Bangsa, Rineka Cipta, Jakarta.

Pasaribu, Amudi, 1981. Pengantar Statistik, Ghalia Indonesia, Jakarta.

Rahim, A., 2008. Sistem Manajemen Agribisnis. State University of Makasar Press

Riyanto, B. 2002. Dasar-Dasar Pembelanjaan Perusahaan. Yayasan Badan Penerbit Gadjah Mada, Yogyakarta.

Saladin, 2003. Marketing, Bumi Aksara, Jakarta

Soekartawi, 2002. Ilmu Usahatani dan Penelitian Untuk Pengembangan Petani Kecil, Penerbit Universitas Indonesia, Jakarta

Soeseno, Slamet. 2000. Bertanam Aren, Penebar Swadaya, Jakarta

Soetriono, A.S. 2006. Pengantar Ilmu Pertanian: Agraris, Agrobisnis dan Industri. Malang: Bayumedia.

Sugiono, 2012. Metode Penelitian Kuantitatif dan $R \& D$, Alfabeta, Bandung

Sudjana, 2003. Teknik Analisis Regresi dan Korelasi. Penerbit Tarsito. Bandung.

Suprapto, 2003. Karakteristik, Penerapan, dan Pengembangan Agroindustri Hasil Pertanian di Indonesia. Jakarta. Universitas Mercu Buana.

Tohar, 2004. Membuka Usaha Kecil. Kanisius. Yokyakarta 